\title{
Canker and Twig Dieback of Blueberry Caused by Pestalotiopsis spp. and a Truncatella sp. in Chile
}

José G. Espinoza and Erika X. Briceño, Facultad de Agronomía e Ingeniería forestal, Pontificia Universidad Católica de Chile, Casilla 306-22, Santiago, Chile; Lisa M. Keith, Tropical Plant Genetic Resource Management Unit, Pacific Basin Agricultural Research Center, United States Department of Agriculture-Agricultural Research Service, Hilo, HI 96720; and Bernardo A. Latorre, Facultad de Agronomía e Ingeniería forestal, Pontificia Universidad Católica de Chile

\begin{abstract}
Espinoza, J. G., Briceño, E. X., Keith, L. M., and Latorre, B. A. 2008. Canker and twig dieback of blueberry caused by Pestalotiopsis spp. and a Truncatella sp. in Chile. Plant Dis. 92:14071414.

Blueberry (Vaccinium spp.) has great economic importance in Chile, which currently has about 8,500 ha being cultivated. Recently, the presence of canker and dieback symptoms has been observed along the productive blueberry zone of Chile. Species of Pestalotiopsis and Truncatella were consistently isolated from diseased samples in 22 different locations. Therefore, the objective of this study was to identify and characterize the species of Pestalotiopsis and Truncatella associated with canker and twig dieback symptoms on blueberry. Forty-nine isolates were obtained on acidified potato dextrose agar in 2006 and 2007. These isolates were identified as Pestalotiopsis clavispora, P. neglecta, and Truncatella (=Pestalotia) angustata on the basis of colony characteristics and conidial morphology. This identification was verified by internal transcribed spacer analysis of DNA. Isolates of P. clavispora, P. neglecta, and T. angustata were pathogenic on apple, kiwifruit, and blueberry fruit. Similarly, isolates of $P$. clavispora were pathogenic on detached blueberry twigs of cv. O'Neal. Additionally, three selected isolates of $P$. clavispora induced light-brown canker lesions, surrounded by a reddish halo, and shoot dieback after twig inoculations on 2-year-old twigs of blueberry cvs. O'Neal, Bluecrop, Brightwell, Brigitta, Duke, Elliot, and Misty. Among blueberry cultivars, Brightwell and O'Neal were the most susceptible and Bluecrop and Misty the least susceptible, while Elliot, Brigitta, and Duke were moderately susceptible to P. clavispora. These pathogens were isolated consistently from inoculated plants, confirming Koch's postulates. P. clavispora was highly sensitive to fludioxonil and pyraclostrobin with a median effective concentration of 0.06 to 0.08 and 0.04 to $0.8 \mu \mathrm{g} / \mathrm{ml}$, respectively. Therefore, the results of this study indicate that $P$. clavispora, $P$. neglecta, and $T$. angustata are primary pathogens that can cause canker lesions and dieback symptoms on blueberry not previously described in Chile. However, these results do not exclude that other species of these genera or other plant-pathogenic fungi (e.g., Botryosphaeria, Pestalotia, and Phomopsis spp.) may eventually be involved in this syndrome of blueberry.
\end{abstract}

Additional keywords: highbush blueberry

Blueberry (Vaccinium spp.) was introduced commercially in 1979 into Chile. Currently, it is a high-value export crop cultivated on nearly 8,500 ha across a range of diverse soil conditions and climate zones. Commercial plantings extend near $1,300 \mathrm{~km}$ along a north-south axis from IV Region (governmental administrative zone) in the north to X Region in the south. Blueberry is mainly grown for the export market in the United States and Europe. Approximately 17,000 t was ex-

Corresponding author: B. A. Latorre

E-mail: blatorre@uc.cl

GenBank accession numbers: EU342211 through EU342217.

Accepted for publication 28 May 2008.

doi:10.1094/PDIS-92-10-1407

(C) 2008 The American Phytopathological Society ported in 2006-07, representing a $\$ 110$ million income. Therefore, it is an important alternative for the agriculture economy of Chile at present $(2,23,28)$.

Several fungal diseases have been reported on blueberry (5). Among these, canker and twig dieback occur frequently in commercial plantings, at 15 and $45 \%$ incidence, respectively, in plantings of bushes between 2 and 15 years old in Chile. In 2003, Cuevas and Acuña identified Pestalotiopsis (=Pestalotia) guepinii associated with foliar and shoot necrosis at nurseries (7).

Pestalotiopsis is a complex genus including more than 225 species (4), with an incomplete validation of some species which makes the morphological identification relatively difficult. In addition, some species were identified only on the basis of their hosts $(11,13)$.

Species of Pestalotiopsis identified as foliar or fruit rot pathogens have been reported from Argentina, Spain, and the United States $(3,6,8)$. In addition, several Pestalotiopsis spp. have been described as pathogens of several plants, including forest, fruit, and ornamental crops $(10,15-$ $18,26,29,35,38)$. To control them, integrated control strategies, including the use of resistant cultivars, sanitation, and chemical control, have been proposed (31,37).

The objective of this study was to identify the Pestalotiopsis spp. causing canker and twig dieback throughout the various blueberry-producing regions of Chile, in order to gain a clearer understanding of the etiology of the disease in this country.

\section{MATERIALS AND METHODS}

Isolations. Samplings were made at six commercial plantings of northern highbush blueberry (Vaccinium corymbosum) and at six plantings of southern highbush blueberry $(V$. corymbosum $\times V$. darrowi). Of 49 isolates that were characterized in this study, $81.6 \%$ were obtained from northern highbush blueberry and $18.4 \%$ were obtained from southern highbush blueberry. The northernmost sampling site was near Nogales $\left(32^{\circ} 60^{\prime}\right.$ South latitude) in a semiarid agricultural region (mean annual rainfall: 341 to $436 \mathrm{~mm}$ ) whereas the southernmost sampling site was near Purranque $\left(40^{\circ} 53^{\prime}\right.$ South latitude) in a high-rainfall agricultural region (mean annual rainfall: 1,381 to $1,542 \mathrm{~mm}$ ). All were at relatively low altitudes in very diverse soil conditions (27; Table 1).

Samples were obtained from 1 to 10 symptomatic plants at each site and transported to the laboratory in an ice chest, and at least five diseased tissue pieces (approximately $5 \mathrm{~cm}^{2}$ ) per 1 - to 2-year-old twigs or crown tissue were surface disinfested in $0.5 \%$ sodium hypochlorite $(\mathrm{NaOCl})$ for $2 \mathrm{~min}$, rinsed in sterile distilled water, and plated on potato dextrose agar acidified with of $96 \%$ lactic acid at $0.5 \mu \mathrm{l} / \mathrm{ml}$ (APDA). Plates were incubated in the dark at $20^{\circ} \mathrm{C}$ for 3 days. Hyphal tips of emerging Pestalotiopsis colonies were transferred to APDA. Pure cultures were maintained at $20^{\circ} \mathrm{C}$.

Morphological characterization. The 44 isolates tentatively identified as Pestalotiopsis spp. and 5 isolates identified as Truncatella spp. were incubated 
at $25^{\circ} \mathrm{C}$ in the dark and colony morphology was examined after 7 days. Conidia morphology (shape, color, and cell number), size (length and width), and the presence and size of apical and basal appendages was determined for 20 to 40 arbitrarily selected conidia from a conidial suspension of each isolate that was prepared in sterile distilled water (SDW). The isolates were identified according to the descriptions of Guba (9), Sutton (32), and Nag Raj (24).

Molecular characterization. Pestalotiopsis isolates (Pc03-06, Pc9.1-06, Pc0107, Pc07-07, Pc17-07, and Pn14-07) and isolate Ta10-07, tentatively identified as a Truncatella sp., were identified using mo- lecular techniques. Total genomic DNA was extracted following the protocol found in Keith et al. (17).

Universal internal transcribed spacer (ITS)1/ITS4 primers were used in the polymerase chain reaction (PCR). The amplification and sequencing of the ITS/5.8S rRNA/ITS2 region was made with the ITS1 primer (5'TCCGTAGGTGAACCT GCGG3') and ITS4 primer (5'TCCTCC GCTTATTATTGATATGC3') (36). PCR amplification was performed in a $50-\mu l$ reaction mixture containing $4 \mu \mathrm{l}$ of template DNA, $3 \mu \mathrm{M}$ each primer, $1 \times \mathrm{PCR}$ buffer (supplied with Taq polymerase), 25 $\mathrm{mM} \mathrm{MgCl}, 2 \mathrm{mM}$ dNTPs, and $0.5 \mathrm{U}$ of Taq polymerase. After an initial hot start $\left(95^{\circ} \mathrm{C}\right.$ for $\left.5 \mathrm{~min}\right), 35 \mathrm{PCR}$ cycles were performed on an MJ Scientific PTC-100 thermocycler using the following conditions: a denaturation step of $95^{\circ} \mathrm{C}$ for $30 \mathrm{~s}$ and annealing at $55^{\circ} \mathrm{C}$ for $60 \mathrm{~s}$ and extension at $72^{\circ} \mathrm{C}$ for $60 \mathrm{~s}$, followed by a final extension of $72^{\circ} \mathrm{C}$ for $6 \mathrm{~min}$.

The products of the amplification were separated through electrophoresis in 1\% agarose gels (Invitrogen Co., San Diego, CA) with electrophoresis at $80 \mathrm{~V} / \mathrm{cm}$ and visualized under UV after staining the gel with ethidium bromide. A 1-kb ladder (Invitrogen) was used as a size marker. PCR products were cloned with the TA cloning kit (Invitrogen) according to the manufacturer's recommendations.

Table 1. Isolates of Pestalotiopsis and Truncatella obtained from commercial blueberry (Vaccinium spp.) plantings in Chile in 2006 and 2007

\begin{tabular}{|c|c|c|c|c|c|}
\hline \multirow[b]{2}{*}{ Codes } & \multirow[b]{2}{*}{ Hosts ${ }^{\mathrm{z}}$} & \multirow[b]{2}{*}{ Cultivars } & \multicolumn{2}{|c|}{ Origin } & \multirow[b]{2}{*}{ Age (years } \\
\hline & & & Locality & Latitude south & \\
\hline \multicolumn{6}{|c|}{ Pestalotiopsis clavispora } \\
\hline Pc2.1-06 & $\mathrm{SH}$ & O’Neal & Nancagua, VI Región & $34^{\circ} 40^{\prime}$ & 3 \\
\hline $\mathrm{Pc} 03-06$ & $\mathrm{SH}$ & Marimba & Lampa, Región Metropolitana & $32^{\circ} 49^{\prime}$ & 1 \\
\hline Pc9.1-06 & $\mathrm{SH}$ & Marimba & Cabildo, V Región & $32^{\circ} 49^{\prime}$ & 3 \\
\hline Pc12-06 & $\mathrm{SH}$ & O’Neal & Cabildo, V Región & $32^{\circ} 49^{\prime}$ & 4 \\
\hline Pc14-06 & $\mathrm{SH}$ & Marimba & Cabildo, V Región & $32^{\circ} 49^{\prime}$ & 4 \\
\hline Pc15-06 & $\mathrm{SH}$ & O’Neal & Cabildo, V Región & $32^{\circ} 49^{\prime}$ & 4 \\
\hline Pc19-06 & NH & Duke & Los Angeles, VIII Región & $37^{\circ} 23^{\prime}$ & 2 \\
\hline Pc20-06 & $\mathrm{SH}$ & Cooper & Melipilla, Region Metropolitana & $33^{\circ} 41^{\prime}$ & 3 \\
\hline Pc20-06a & NH & Duke & Los Angeles, VIII Región & $37^{\circ} 23^{\prime}$ & 2 \\
\hline Pc21-06 & NH & Duke & Los Angeles, VIII Región & $37^{\circ} 23^{\prime}$ & 2 \\
\hline Pc22-06 & $\mathrm{SH}$ & Cooper & Melipilla, Region Metropolitana & $33^{\circ} 41^{\prime}$ & 2 \\
\hline Pc01-07 & $\mathrm{SH}$ & O’Neal & Nogales, V Región & $32^{\circ} 60^{\prime}$ & 2 \\
\hline Pc03-07 & NH & Aurora & Río Negro, Osorno, X Región & $40^{\circ} 45^{\prime}$ & 2 \\
\hline Pc07-07 & NH & Brigitta & Río Negro, Osorno, X Región & $40^{\circ} 45^{\prime}$ & 5 \\
\hline Pc08-07 & NH & Brigitta & Río Negro, Osorno, X Región & $40^{\circ} 45^{\prime}$ & 5 \\
\hline Pc13-07 & NH & Brigitta & Río Negro, Osorno, X Región & $40^{\circ} 45^{\prime}$ & 15 \\
\hline Pc15-07 & NH & Liberty & Purranque, Osorno, X Región & $40^{\circ} 53^{\prime}$ & 2 \\
\hline Pc16-07 & NH & Liberty & Purranque, Osorno, X Región & $40^{\circ} 53^{\prime}$ & 2 \\
\hline Pc17-07 & NH & Liberty & Purranque, Osorno, X Región & $40^{\circ} 53^{\prime}$ & 2 \\
\hline Pc18-07 & NH & Liberty & Purranque, Osorno, X Región & $40^{\circ} 53^{\prime}$ & 2 \\
\hline Pc19-07 & NH & Liberty & Purranque, Osorno, X Región & $40^{\circ} 53^{\prime}$ & 2 \\
\hline Pc20-07 & NH & Liberty & Purranque, Osorno, X Región & $40^{\circ} 53^{\prime}$ & 2 \\
\hline Pc29-07 & $\mathrm{NH}$ & Bluecrop & Purranque, Osorno, X Región & $40^{\circ} 53^{\prime}$ & 2 \\
\hline Pc30-07 & $\mathrm{NH}$ & Bluecrop & Purranque, Osorno, X Región & $40^{\circ} 53^{\prime}$ & 2 \\
\hline Pc39-07 & $\mathrm{NH}$ & Legacy & Purranque, Osorno, X Región & $40^{\circ} 53^{\prime}$ & 2 \\
\hline Pc40-07 & NH & Liberty & Purranque, Osorno, X Región & $40^{\circ} 53^{\prime}$ & 2 \\
\hline $\operatorname{Pc} 41-07$ & NH & Liberty & Purranque, Osorno, X Región & $40^{\circ} 53^{\prime}$ & 2 \\
\hline Pc22-07 & NH & Liberty & Purranque, Osorno, X Región & $40^{\circ} 53^{\prime}$ & 2 \\
\hline Pc24-07 & NH & Liberty & Purranque, Osorno, X Región & $40^{\circ} 53^{\prime}$ & 2 \\
\hline Pc21-07 & NH & Liberty & Purranque, Osorno, X Región & $40^{\circ} 53^{\prime}$ & 2 \\
\hline Pc27-07 & $\mathrm{NH}$ & Bluecrop & Purranque, Osorno, X Región & $40^{\circ} 53^{\prime}$ & 2 \\
\hline Pc34-07 & $\mathrm{NH}$ & Legacy & Purranque, Osorno, X Región & $40^{\circ} 53^{\prime}$ & 2 \\
\hline Pc35-07 & $\mathrm{NH}$ & Legacy & Purranque, Osorno, X Región & $40^{\circ} 53^{\prime}$ & 2 \\
\hline Pc36-07 & $\mathrm{NH}$ & Legacy & Purranque, Osorno, X Región & $40^{\circ} 53^{\prime}$ & 2 \\
\hline Pc38-07 & $\mathrm{NH}$ & Legacy & Purranque, Osorno, X Región & $40^{\circ} 53^{\prime}$ & 2 \\
\hline Pc53-07 & NH & Liberty & Purranque, Osorno, X Región & $40^{\circ} 53^{\prime}$ & 2 \\
\hline Pc56-07 & NH & Liberty & Purranque, Osorno, X Región & $40^{\circ} 53^{\prime}$ & 2 \\
\hline Pc60-07 & $\mathrm{NH}$ & Elliot & Purranque, Osorno, X Región & $40^{\circ} 53^{\prime}$ & 2 \\
\hline Pc68-07 & NH & Brigitta & Río Negro, Osorno, X Región & $40^{\circ} 45^{\prime}$ & 2 \\
\hline Pc74-07 & NH & Brigitta & Río Negro, Osorno, X Región & $40^{\circ} 45^{\prime}$ & 2 \\
\hline \multicolumn{6}{|l|}{ P. neglecta } \\
\hline Pn14-07 & $\mathrm{NH}$ & Brigitta & Río Negro, Osorno, X Región & $40^{\circ} 45^{\prime}$ & 15 \\
\hline Pn50-07 & $\mathrm{NH}$ & Liberty & Purranque, Osorno, X Región & $40^{\circ} 53^{\prime}$ & 2 \\
\hline Pn61-07 & $\mathrm{NH}$ & Elliot & Purranque, Osorno, X Región & $40^{\circ} 53^{\prime}$ & 2 \\
\hline Pn09-07 & $\mathrm{NH}$ & Brigitta & Río Negro, Osorno, X Región & $40^{\circ} 45^{\prime}$ & 15 \\
\hline \multicolumn{6}{|c|}{ Truncatella angustata } \\
\hline Ta10-07 & NH & Brigitta & Río Negro, Osorno, X Región & $40^{\circ} 45^{\prime}$ & 15 \\
\hline Ta11-07 & NH & Brigitta & Río Negro, Osorno, X Región & $40^{\circ} 45^{\prime}$ & 15 \\
\hline Ta31-07 & NH & Bluecrop & Purranque, Osorno, X Región & $40^{\circ} 53^{\prime}$ & 2 \\
\hline Ta48-07 & NH & Liberty & Purranque, Osorno, X Región & $40^{\circ} 53^{\prime}$ & 2 \\
\hline Ta51-07 & NH & Liberty & Purranque, Osorno, X Región & $40^{\circ} 53^{\prime}$ & 2 \\
\hline
\end{tabular}

${ }^{\mathrm{z}} \mathrm{NH}=$ northern highbush $($ Vaccinium corymbosum $)$ and $\mathrm{SH}=$ southern highbush $($ V. corymbosum $\times$ V. darrowi $)$. 
Plasmid DNA for sequencing was prepared with the Qiagen plasmid miniprep kit according to the recommendations of the manufacturer (Qiagen, Inc., Chatsworth, CA). DNA sequencing was performed at MWG Biotech Inc. (High Point, $\mathrm{NC})$. Sequence data were aligned and were compared with the sequences reported in the GenBank database using the National Center for Biotechnology Information BLAST Network Server (1). The sequences had the $3^{\prime}$ end of the 18S rRNA gene, ITS1, 5.8 rRNA gene, ITS2, and the 5 ' end of the $28 \mathrm{~S}$ rRNA gene. A multiple sequence alignment was constructed using CLUSTALX (34). A phylogenetic analysis, using the ITS/5.8S rDNA/ITS2 sequences, was constructed by the Neighbor-Joining method $(17,30)$.

Effect of temperature on mycelial growth. The effect of temperature on the mycelial growth of Pestalotiopsis spp. (Pc03-06, Pc9.1-06, Pc01-07, Pc07-07, Pc17-07, and Pn14-07) and a Truncatella sp. (Ta10-07) was determined in petri dishes $(90 \mathrm{~mm}$ in diameter) containing APDA. Four petri dishes were inoculated centrally with an agar disk $(5 \mathrm{~mm}$ in diameter) obtained from 3-day-old cultures in APDA. Plates were incubated at 0,5 , $10,15,20,25,30$, and $35^{\circ} \mathrm{C}\left( \pm 1^{\circ} \mathrm{C}\right)$ for 6 days in the dark. The effect of temperature was determined through the radial growth of the mycelium. These experiments were conducted twice.

Pathogenicity tests. Pestalotiopsis isolates Pc03-06, Pc9.1-06, Pc01-07, Pc0707, Pc17-07, and Pn14-07 and Truncatella isolate Ta10-07 were tested for pathogenicity on surface-disinfested fruit $(0.5 \%$ $\mathrm{NaOCl}$ for $60 \mathrm{~s}$ and $0.05 \%$ ethanol for 60 s) of apple (cv. Granny Smilth) and kiwi (cv. Hayward). Wounded and nonwounded fruit were inoculated with a mycelium plug ( $5 \mathrm{~mm}$ in diameter) taken from pure cultures on APDA. An equal number of fruit were inoculated with sterile APDA and left as controls. The diameter of the lesion developed was measured after 6 days of incubation at $20^{\circ} \mathrm{C}$ in humid chambers at $100 \%$ relative humidity $(\mathrm{RH})$, determined with a RH sensor (StowAway RH, Columbus, $\mathrm{OH})$. Isolate Pc01-07 of Pestalotiopsis was also tested on mature fruit of blueberry (cv. Jewell) that were wounded with a hypodermic syringe and were incubated as indicated above for 10 days.

Pathogenicity tests were repeated on wounded fruit of apple (cv. Granny Smith), kiwifruit (cv. Hayward), and blueberry fruit using conidia as inoculum. The isolate Pc01-07 of P. clavispora was also tested on mature blueberry fruit cv. Jewell that were wounded as indicated above. Each fruit was inoculated with $15 \mu$ of conidia suspension $\left(10^{6}\right.$ conidia/ml $)$ prepared in SDW from Pestalotiopsis isolates Pc01-07 and Pc17-07 and Truncatella isolate Ta10-07. These isolates were selected because of their high aggressiveness after mycelia inoculation. Fruit were incubated for 10 days as described above before determining the diameter of the lesion developed.

Pestalotiopsis isolates that were pathogenic on fruit were tested for pathogenicity on lignified (2-year-old) detached blueberry twigs of cv. O'Neal and on twigs from 2-year-old potted blueberry plants (cvs. Bluecrop, Brigitta, Brightwell, Duke, Elliot, Misty, and O'Neal). Surface-disinfested $(0.5 \% \mathrm{NaOCl}, 60 \mathrm{~s})$ twigs of about $20 \mathrm{~cm}$ in length and similar in diameter were used. Each detached twig was inoculated with either a piece $(5 \mathrm{~mm}$ in diameter) of mycelium taken from a 7-day-old culture on APDA or $15 \mu \mathrm{l}$ of a $10^{6}$ conidia/ml conidial suspension in SDW of isolates Pc9.1-06, Pc01-07, and Pc17-07. Potted plants were inoculated with mycelium of isolates Pc03-06, Pc9.1-06, and Pc17-07 and this experiment was repeated with conidia of isolate Pc01-07. The inoculum was deposited on a 5-mm-long tangential cut made aseptically in the bark. The inoculation site was covered for 3 days with Parafilm (Plastic Parking, Chicago). An equal number of injured but noninoculated twigs were left as controls. All detached twigs were incubated in $100 \% \mathrm{RH}$ for 25 days at $20^{\circ} \mathrm{C}$ and potted plants were maintained under semi-shaded conditions with temperatures varying from 18 to $25^{\circ} \mathrm{C}$ for 15 days. The length of the necrotic lesion obtained was determined.

To fulfill Koch's postulates, pieces of tissue obtained from diseased fruit and twigs were plated on APDA to reisolate the causal agent that was identified on the basis colony and conidial morphology.

Sensitivity to fungicides. The sensitivity of $P$. clavispora (Pc03-06, Pc9.1-06, and Pc17-07) to boscalid (Cantus $50 \mathrm{WG}$; BASF, Santiago, Chile), chlorothalonil (Horta 50 F; Agrícola Nacional SACI,
Santiago, Chile) cyprodinil (Vangard 50 WP; Syngenta Crop Protection, Santiago Chile), fludioxonil (Scholar 230 SC; Syngenta Crop Protection), iprodione (Rovral 4F; Bayer Crop Science, Santiago, Chile), and pyraclostrobin (Comet $250 \mathrm{SL}$; BASF) was studied in vitro. These fungicides were selected from among the recommended fungicides for controlling other diseases of blueberry in Chile. Each fungicide was tested on APDA amended with a discriminatory rate of each fungicide at $1 \mu \mathrm{g} / \mathrm{ml}$ that was added in water to sterile medium cooled to approximately $60^{\circ} \mathrm{C}$. Mycelium plugs ( $5 \mathrm{~mm}$ in diameter) of each isolate was seeded in quadruplicated petri dishes (90 $\mathrm{mm}$ in diameter) and incubated for 5 days at $25^{\circ} \mathrm{C}$ in complete darkness before the radial growth of the mycelium was determined.

The median effective concentration $\left(\mathrm{EC}_{50}\right)$ of fludioxonil and pyraclostrobin, the most effective fungicides in the first experiment, was determined. Mycelium plugs from isolates Pc03-06, Pc9.1-06, and Pc17-07 were inoculated onto petri dishes containing APDA modified with the respective fungicide at $0.0,0.025,0.05,0.5$, $0.1,1.0$, or $1.5 \mu \mathrm{g} / \mathrm{ml}$. All cultures were incubated at $25^{\circ} \mathrm{C}$ for 5 days in complete darkness before determining the radial growth of the mycelium. Results were expressed as efficacy $(E)=([A-B] / A) \times$ 100 , where $A$ was the diameter of the colony on APDA without fungicide and B was the diameter of the colony on APDA with fungicide.

Design and statistical analysis. Pathogenicity tests performed on apple and kiwi were designed as a complete randomized design of 7 by 2 (isolates by inoculation method) with factorial arrangement of treatments and four replicates of one fruit each. The experiments conducted to study the effect of tempera-

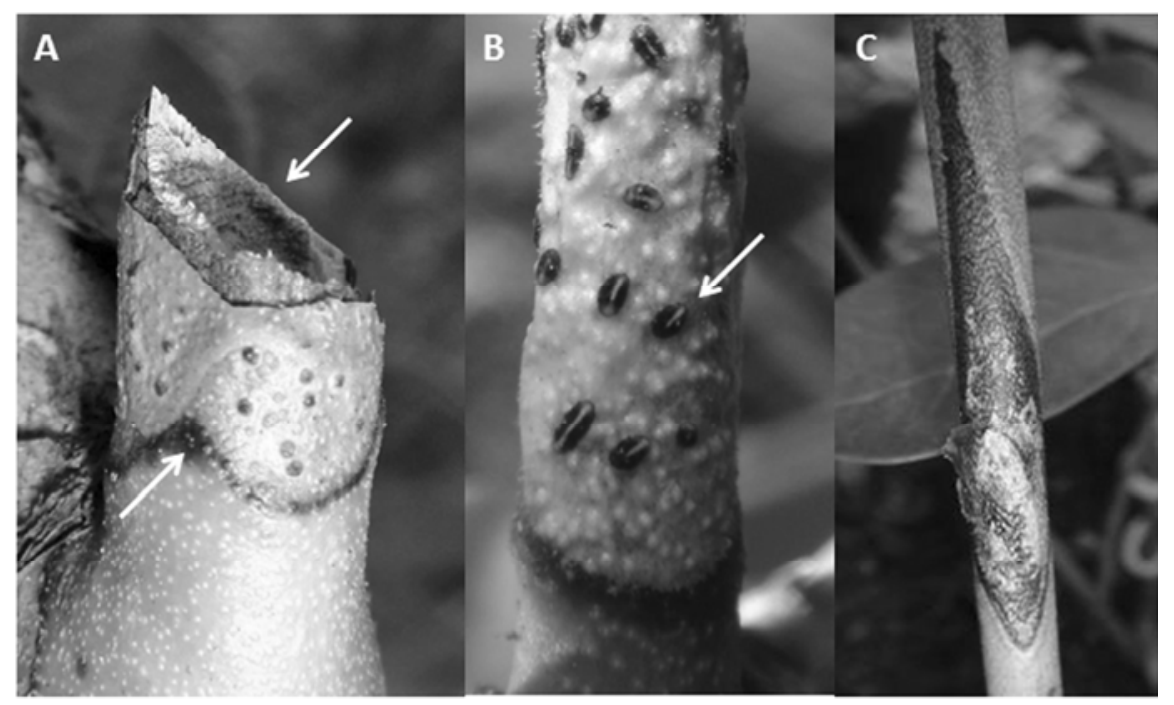

Fig. 1. Cankers caused by Pestalotiopsis spp. in blueberry (Vaccinium spp.). A and B, Naturally infected plants. A, Canker developed below a pruning wound (arrow) surrounded by a reddish line (arrow). B, Light-brown canker with black ellipsoidal black acervuli (arrow). C, Cankered lesion obtained on inoculated blueberry stem cv. O'Neal. 
ture on the mycelium growth and pathogenicity tests in blueberry fruit and detached blueberry twigs were designed as a complete randomized design with four replicates. Pathogenicity tests conducted on potted blueberry plants were designed as a complete block design with a 7 by 3 (cultivar by isolates) factorial arrangement of treatment with four replicates each consisting of one potted plant. The results were studied for analysis of variance cording to Tukey, using SAS PROC GLM and SAS PROC MEANS, respectively (SAS Institute, Cary, NC).

The $\mathrm{EC}_{50}$ values of each fungicide was determined by linear regression analysis where $y=$ Probit $\% \mathrm{E}$ and $x=\log$ fungicide concentration of each fungicide; SAS Probit was used. (ANOVA) and means were separated ac-

\section{RESULTS}

Field observations and isolations. Diseased plants were characterized by the presence of reddish to dark-brown necrotic lesions on twigs, at the basal portion of the main stems, and at the crown of the plants. Extensive necrotic lesions were observed below the bark, and dark-brown vascular damage was frequently observed. Apical necrosis and twig dieback occurred on affected twigs. Stem symptoms were frequently associated with pruning wounds, extending several centimeter below wounds (Fig. 1). Abundant black acervuli were observed on dead tissue. Usually, plants were partially affected but, eventually, the complete plant collapsed.

Pestalotiopsis spp. (44 isolates) and Truncatella spp. (5 isolates) were consistently isolated from 4- to 15-year-old $V$.

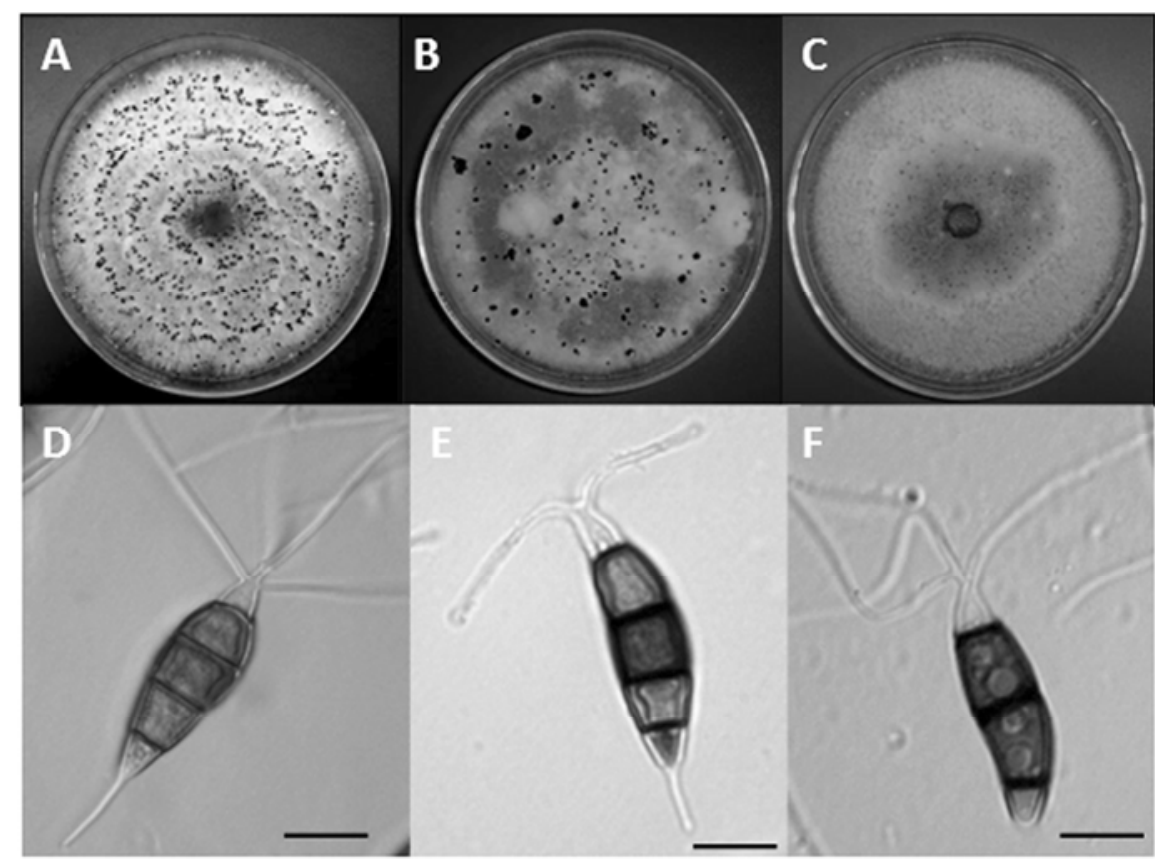

Fig. 2. Colony and conidia of Pestalotiopsis spp. and a Truncatella sp. on acidified potation dextrose agar at $20^{\circ} \mathrm{C}$ for 7 days. A, Pestalotiopsis clavispora with acervuli radially distributed; B, P. neglecta, with acervuli dispersed; and $\mathbf{C}$, Truncatella angustata, acervuli dispersed in the center. Conidia: $\mathbf{D}, P$. clavispora, five-celled, four septa, curved, short apical appendages; E, P. neglecta, five-celled, four septa, curved, relatively short apical appendages with round ends; and F, T. angustata, four brownish cells, three dark brown septa, basal appendage absent. Bars $=10 \mu \mathrm{m}$. corymbosum (cvs. Brigitta, Bluecrop, Duke, Elliot, Legacy, and Liberty), and $V$. corymbosum $\times V$. darrowi (cvs. Cooper, Marimba, and O’Neal) in 12 commercial plantings in Chile. A Truncatella sp. was obtained from samples of $V$. corymbosum (cvs. Brigitta, Bluecrop, and Liberty) obtained in two commercial plantings in the $\mathrm{X}$ Region of Chile (Table 1).

Morphological characterization. Isolates of Pestalotiopsis were characterized by the presence of five-cell conidia with a single hyaline basal appendage and two to four hyaline apical appendages; it was more common to find conidia with four than two appendages. The three median conidial cells were thick-walled and light to dark brown, whereas the apical and basal cells were hyaline (Fig. 2). Colonies were white and cottony, becoming darker as fungi aged on APDA. Black acervuli conidiomata (approximately $0.1 \mathrm{~mm}$ long) were formed superficially and scattered on the agar medium, covered with mycelium (isolates Pc07-07 and Pc9.106) or uncovered (isolates Pc03-06, Pc0107, Pc17-07, and Pn14-07). Isolates Pc03-06, Pc9.1-06, and Pn14-07 were light brown to yellow on the reverse of the APDA plates and isolate Pc17-07 produced a UV fluorescent pigment. Isolates Pc01-07 and Pc07-07 were dull white to cream or yellowish brown.

On the basis of the morphological characterization, two species of Pestalotiopsis were identified.

Conidia of $P$. clavispora (G.F. Atk.) Steyaert were straight fusiform with three colored median cells, the upper two cells being dark brown and the lowest median cell being olivaceous. Conidia were always smooth with mean \pm standard deviation of $22.7 \pm 2.3$ to $27.0 \pm 2.5 \mu \mathrm{m}$ long (L) and $7.4 \pm 0.3$ to $9.3 \pm 0.7 \mu \mathrm{m}$ wide (W). The $\mathrm{L}: \mathrm{W}$ ratio varied from $2.5 \pm 0.4$ to $3.6 \pm 0.7$. Two to four (usually three) apical appendages and one basal appendage were always observed. Apical appendages varied from 20.4 to $32.1 \mu \mathrm{m}$, while the basal appendage varied from 7.0 to $8.7 \mu \mathrm{m}$ (Table 2). On APDA, colonies were zonate or nonzonate and abun-

Table 2. Characteristics of the conidia of Pestalotiopsis clavispora, P. neglecta, and Truncatella angustata obtained from blueberry (Vaccinium spp.) in Chile

\begin{tabular}{|c|c|c|c|c|c|c|c|}
\hline \multirow[b]{3}{*}{ Isolates } & \multirow{2}{*}{\multicolumn{3}{|c|}{ Conidia $^{z}$}} & \multicolumn{4}{|c|}{ Appendages $^{\mathrm{z}}$} \\
\hline & & & & \multicolumn{2}{|c|}{ Apical } & \multicolumn{2}{|c|}{ Basal } \\
\hline & Length $(L)(\mu \mathrm{m})$ & Width $(W)(\mu \mathrm{m})$ & L:W & No. & Length $(\mu \mathrm{m})$ & No. & Length $(\mu \mathrm{m})$ \\
\hline \multicolumn{8}{|l|}{ P. clavispora } \\
\hline Pc03-06 & $23.6 \pm 2.6$ & $7.6 \pm 0.6$ & $3.1 \pm 0.4$ & $2-4$ & 20.4 & 1 & 8.7 \\
\hline Pc9.1-06 & $23.0 \pm 1.6$ & $7.4 \pm 0.3$ & $3.1 \pm 0.2$ & $2-4$ & 21.5 & 1 & 7.0 \\
\hline Pc01-07 & $25.2 \pm 2.5$ & $8.6 \pm 0.9$ & $3.0 \pm 0.4$ & $2-4$ & 25.3 & 1 & 7.3 \\
\hline Pc07-07 & $22.7 \pm 2.3$ & $9.3 \pm 0.7$ & $2.5 \pm 0.4$ & $2-4$ & 20.4 & 1 & 8.0 \\
\hline Pc17-07 & $26.1 \pm 2.4$ & $7.4 \pm 0.9$ & $3.6 \pm 0.7$ & $2-4$ & 32.1 & 1 & 7.1 \\
\hline \multicolumn{8}{|l|}{ P. neglecta } \\
\hline Pn14-07 & $27.0 \pm 2.5$ & $7.0 \pm 0.9$ & $3.9 \pm 0.6$ & $3-4$ & 17.3 & 1 & 4.8 \\
\hline \multicolumn{8}{|l|}{ T. angustata } \\
\hline Ta10-07 & $20.1 \pm 1.4$ & $6.3 \pm 0.5$ & $3.2 \pm 0.4$ & $2-4$ & 13.7 & 0 & 0.0 \\
\hline
\end{tabular}

${ }^{\mathrm{z}}$ Means from 25 to 40 conidia per isolate \pm standard deviation. 
dant black acervuli developed after 7 days.

Conidia of P. neglecta (Thüm.) Steyaert were fusiform and slightly curved with three colored median cells, the upper two cells being brown to yellow brown and the lowest cell being olivaceous. Conidia were always smooth, $27.0 \pm 2.5 \mu \mathrm{m}$ long and $7.0 \pm 0.9 \mu \mathrm{m}$ wide, with a $\mathrm{L}: \mathrm{W}$ relation of $3.9 \pm 0.6$. Three to four apical (usually three) appendages with a rounded apical end and one basal appendage were always observed. Apical appendages were $17.3 \mu \mathrm{m}$ and the basal appendage was $4.8 \mu \mathrm{m}$ in length (Table 2 ). On APDA, nonzonate colonies and scattered black acervuli were produced after 7 days.
Truncatella isolates produced four-cell conidia, straight to slightly curved on APDA. Conidia had hyaline apical and basal cells with two brown to dark-brown median cells, which were thick-walled with an unfinished basal cell. Septa were prominent. More than one hyaline apical appendage, variable in size and branched dichotomically, was observed. No basal appendages were present (Fig. 2).

These Truncatella isolates were identified as T. angustata (Pers.) S. Hughes, exhibiting a relatively fast mycelial growth on APDA (7 mm/day) at $20^{\circ} \mathrm{C}$ (Fig. 3). They developed dull white to brown, cottony colonies with black acervuli (about 1 $\mathrm{mm}$ long) mainly in the center of the APDA plates after 7 to 10 days. A dark-

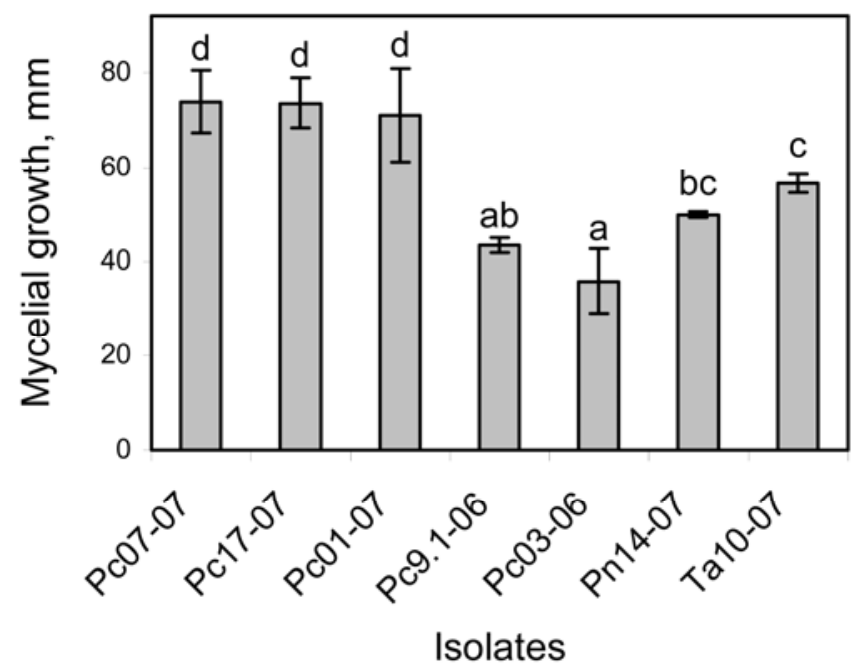

Fig. 3. Mean mycelial growth ( \pm standard deviation) of Pestalotiopsis clavispora $(\mathrm{Pc})$, P. neglecta $(\mathrm{Pn})$, and Truncatella angustata (Ta) after 6 days at $20^{\circ} \mathrm{C}$ on acidified potation dextrose agar. Means followed by the same letters are not significantly different according to Tukey's test $(P=0.05)$.

brown pigmentation stained the reverse of the APDA agar plates. Conidia were (mean \pm standard deviation) $20.11 \pm 1.39$ by 6.29 $\pm 0.53 \mu \mathrm{m}$ with a $\mathrm{L}: \mathrm{W}$ ratio of $3.22 \pm 0.53$, and typically contained median cells which were dark brown with very pronounced septa.

Molecular characterization. The PCR product had 549 to 605 bp for all six Pestalotiopsis isolates tested, and sequences of 549 to 550 nucleotides of each isolate were used for analysis. The phylogenetic analysis using ITS sequence alignment from the ITS1/5.8S rDNA/ITS2 region separated the six Pestalotiopsis isolates and one isolate of Truncatella obtained from blueberry into two clusters. Cluster I contained isolates Pc03-06, Pc9.1-06, Pc01-07, Pc07-07, and Pc17-07. Cluster II contained isolates Pn14-07 and Ta10-07 (Fig. 4). Isolates of cluster I, morphologically identified as species of Pestalotiopsis, showed a high similarity with known $P$. clavispora sequences, whereas isolate Pn14-07 was highly similar to P. neglecta. However, a considerable variation was obtained among isolates of $P$. clavispora. The Truncatella isolate (Ta10-07) was genetically similar to $T$. angustata and it did not differ from P. neglecta (Fig. 4).

Effect of temperature on mycelial growth. Temperature and isolates had a significant effect $(P<0.0001)$ on radial mycelial growth of Pestalotiopsis and Truncatella isolates. Likewise, the interaction between the temperature and the isolates was significant $(P<0.0001)$. The isolates of $P$. clavispora grew at a temperature range of 5 to $30^{\circ} \mathrm{C}, P$. neglecta grew from 5 to $25^{\circ} \mathrm{C}$, and $T$. angustata grew from 0 to $30^{\circ} \mathrm{C}$. The optimum mycelia

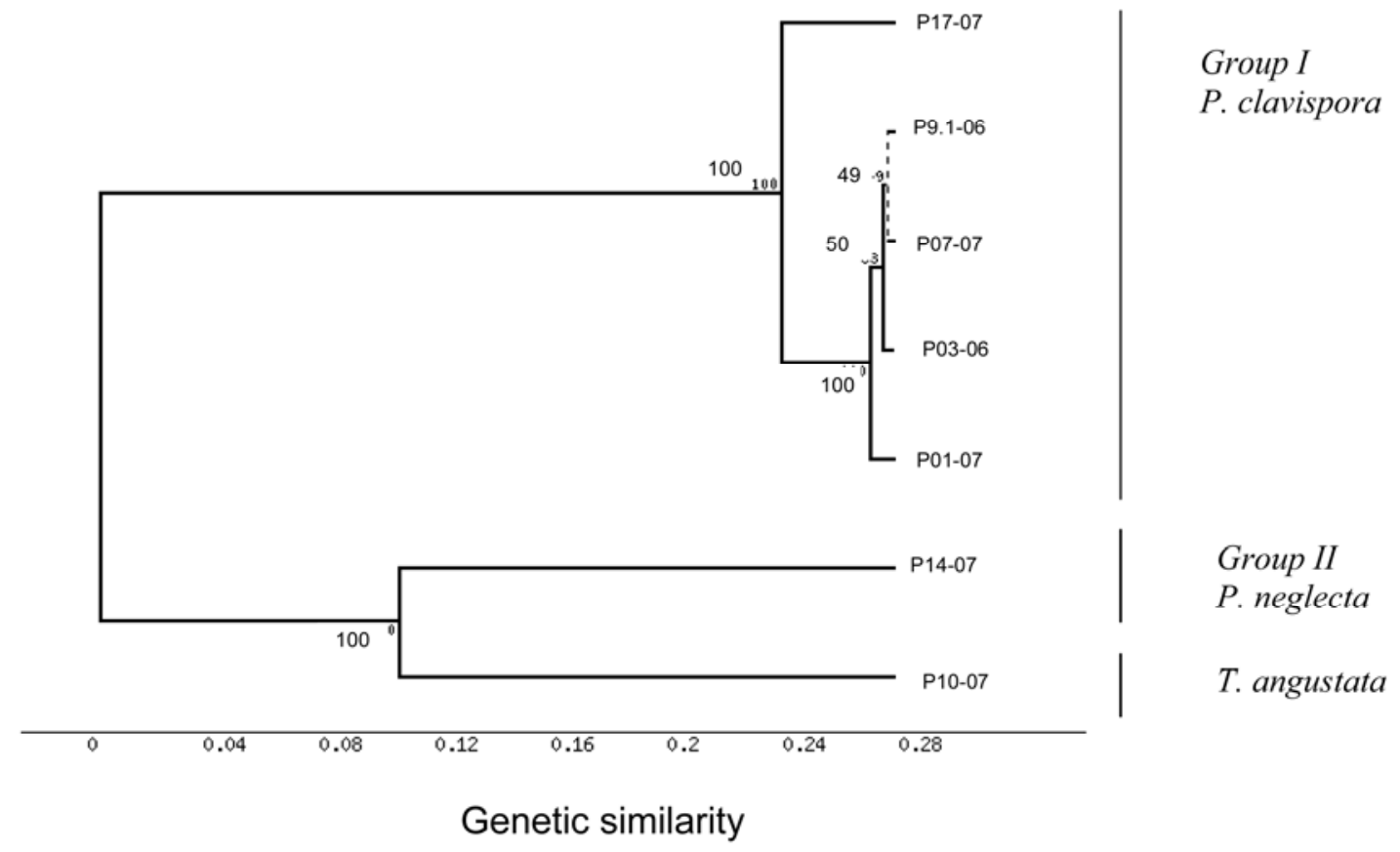

Fig. 4. Phylogenetic analysis of isolates of Pestalotiopsis spp. and a Truncatella sp. on the basis of internal transcribed spacer and 5.8s rDNA analysis. 

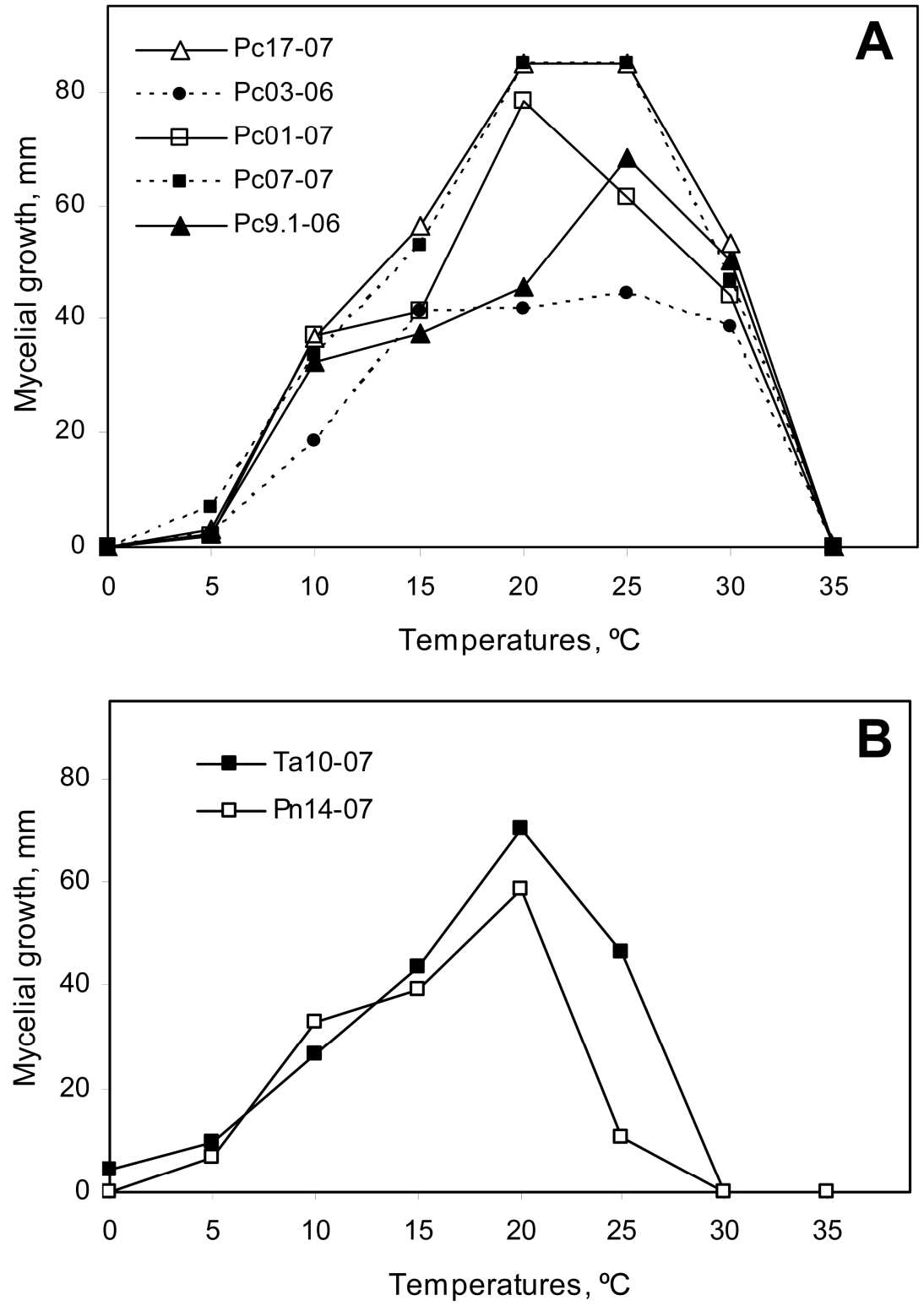

Fig. 5. Effect of the temperature on radial mycelial growth after 6 days on acidified potation dextrose agar. A, Pestalotiopsis clavispora $(\mathrm{Pc})$. B, P. neglecta $(\mathrm{Pn})$ and Truncatella angustata $(\mathrm{Ta})$.

growth among isolates of $P$. clavispora occurred between 18 and $25^{\circ} \mathrm{C}$, and was $20^{\circ} \mathrm{C}$ for isolates of $P$. neglecta and $T$. angustata (Fig. 5).

Significant differences $(P<0.05)$ were obtained among isolates of $P$. clavispora, $P$. neglecta, and $T$. angustata in mycelia growth rate on APDA at $20^{\circ} \mathrm{C}$. Fast-growing $(>8 \mathrm{~mm} /$ day) and relatively slowgrowing $(<5 \mathrm{~mm} /$ day) isolates were found among $P$. clavispora whereas $P$. neglecta and T. angustata were intermediate (Fig. $3)$.

Pathogenicity tests. Mycelium and conidia of all tested isolates of $P$. clavispora, $P$. neglecta, and $T$. angustata were pathogenic on wounded fruit of blueberry, apple, and kiwifruit. A partial light-brown soft rot developed 7 to 10 days after inoculation. Superficial white mycelium and small black acervuli were produced as the rots progressed with age. Unwounded fruit remained unaffected. The effect of isolates and inoculation methods (wounded and unwounded) and the interaction between isolates and inoculation methods were significant $(P<0.001)$. Differences in the size of the rot lesions obtained significantly varied among isolates (Table 3). Similarly, P. clavispora (Pc01-07) developed a soft rot when inoculated on mature wounded blueberry fruit. Pestalotiopsis spp. or Truncatella spp. were consistently reisolated from diseased tissues obtained from inoculated fruit of apple, kiwi, and blueberry.

Symptoms on detached O'Neal blueberry twigs appeared within 2 weeks after inoculation with mycelium or conidia of $P$. clavispora (Table 4). Symptoms consisted of reddish-brown necrotic lesions (12.3 to $16.5 \mathrm{~mm}$ in length) that covered the internal tissues almost completely. A lightbrown vascular necrosis was observed, and white mycelium with small black acervuli was produced on diseased tissues as the age of the lesion increased. The ANOVA indicated that isolates had a significant $(P$ $<0.001$ ) effect on the length of the lesion obtained. Reisolations of $P$. clavispora were successful from diseased tissues developed in inoculated twigs.

Two weeks after inoculations with $P$. clavispora (Pc03-06, Pc9.1-06, and Pc1707), brown necrotic lesions (13.3 to 38.5 $\mathrm{mm}$ in length), often surrounded by a reddish halo, were obtained on 2-year-old twigs of potted blueberry plants of cvs. Bluecrop, Brigitta, Brightwell, Duke, Elliot, Misty, and O'Neal. The ANOVA revealed that average lesion length differed significantly depending on the isolate inoculated $(P<0.001)$ and blueberry cultivars $(P<0.006)$. However, a nonsignificant interaction $(P=0.74)$ between cultivars and isolates was obtained. Independent of the $P$. clavispora isolate, Brightwell was the most susceptible and Bluecrop the least susceptible cultivar, with mean lesions of 28.2 and $16.2 \mathrm{~mm}$ in length, respectively. Regardless of the cultivar, significant differences among $P$. clavispora isolates were obtained, with isolates Pc3-06 and Pc17.07 the most virulent and least virulent, respectively. Reisolations from diseased tissue obtained at the margins of the lesions developing on inoculated twigs consistently yielded $P$. clavispora (Table 5).

Sensitivity to fungicides. The effect of the fungicide treatments and isolates of $P$. clavispora on radial mycelial growth and their interaction were significant $(P<$ 0.047). At $1 \mu \mathrm{g} / \mathrm{ml}$, fludioxonil was the most efficient fungicide, completely inhibiting mycelial growth, followed by pyraclostrobin (85 to $90 \%$ ), iprodione (30 to $40 \%$ ), cyprodonil (20 to $40 \%$ ), chlorothalonil (28 to $35 \%$ ), and boscalid (9 to $39 \%$ ).

The $\mathrm{EC}_{50}$ values estimated for fludioxonil and pyraclostrobin, which were the most efficient fungicides in the first experiment, varied from 0.06 to 0.08 and 0.04 to $0.80 \mu \mathrm{g} / \mathrm{ml}$, respectively. A linear regression best explained the relation between mycelia growth and fungicide concentration $\left(R^{2}=0.84\right.$ to 0.98$)$.

\section{DISCUSSION}

According to the results obtained, Pestalotiopsis clavispora (syn. Pestalotia clavispora G.F. Atk.), Pestalotiopsis neglecta (syn. Pestalotia neglecta Thüm.), and T. angustata (Pers.) (syn. Pestalotia angustata (Pers.) Arx) were identified for the first time associated with canker and twig dieback of blueberry in Chile. The morphological identification was consistent with previous descriptions of these species $(9,12,14,17,19,20,24,32,33)$.

A high homology (>98\%) was obtained for isolates of each of the identified species in relation to reference species reported by the GenBank (25), confirming 
Table 3. Pathogenicity of Pestalotiopsis clavispora, P. neglecta, and Truncatella angustata in fruit of apple and kiwifruit, using mycelia and conidia, determined 7 and 10 days postinoculation, respectively, at $20^{\circ} \mathrm{C}^{\mathrm{z}}$

\begin{tabular}{|c|c|c|c|c|c|}
\hline \multirow[b]{3}{*}{ Isolates } & \multicolumn{5}{|c|}{ Diameter $(\mathbf{m m})$ of lesion obtained on fruit of } \\
\hline & \multicolumn{2}{|c|}{ Apple cv. Granny Smith } & \multicolumn{2}{|c|}{ Kiwifruit cv. Hayward } & \multirow{2}{*}{$\begin{array}{c}\text { Blueberry cv. Jewell } \\
\text { Conidia }\end{array}$} \\
\hline & Mycelia & Conidia & Mycelia & Conidia & \\
\hline \multicolumn{6}{|l|}{ P. clavispora } \\
\hline Pc03-06 & $9.2 \mathrm{bc}$ & nd & $10.0 \mathrm{c}$ & nd & nd \\
\hline Pc9.1-06 & $13.7 \mathrm{bcd}$ & nd & $10.0 \mathrm{c}$ & nd & nd \\
\hline Pc01-07 & $9.2 \mathrm{bc}$ & $15.7 \mathrm{~b}$ & $15.5 \mathrm{~d}$ & $7.5 \mathrm{c}$ & $5.6 \mathrm{~b}$ \\
\hline Pc07-07 & $7.2 \mathrm{ab}$ & nd & $13.7 \mathrm{~cd}$ & nd & nd \\
\hline Pc17-07 & $17.2 \mathrm{~d}$ & $11.5 \mathrm{~b}$ & $13.7 \mathrm{~cd}$ & $7.0 \mathrm{bc}$ & nd \\
\hline \multicolumn{6}{|l|}{ P. neglecta } \\
\hline Pn14-07 & $9.7 \mathrm{bc}$ & nd & $5.0 \mathrm{~b}$ & nd & nd \\
\hline \multicolumn{6}{|l|}{ T. angustata } \\
\hline Ta10-07 & $15.0 \mathrm{~cd}$ & $15.0 \mathrm{~b}$ & $15.7 \mathrm{~d}$ & $5.7 \mathrm{~b}$ & nd \\
\hline \multicolumn{6}{|l|}{ Control } \\
\hline Uninoculated & $0.0 \mathrm{a}$ & $0.0 \mathrm{a}$ & $0.0 \mathrm{a}$ & $0.0 \mathrm{a}$ & $0.0 \mathrm{a}$ \\
\hline
\end{tabular}

Table 4. Pathogenicity of isolates of Pestalotiopsis clavispora on detached twigs of blueberry (Vaccinium corymbosum $\times$ V. darrowi) $\mathrm{cv}$. O'Neal 25 days postinoculation at 20 to $25^{\circ} \mathrm{C}^{\mathrm{z}}$

\begin{tabular}{lcc}
\hline & \multicolumn{2}{c}{ Lesion length $(\mathbf{m m})$} \\
\cline { 2 - 3 } Isolates & Mycelia & Conidia \\
\hline Pc9.1.06 & $16.5 \mathrm{~b}$ & $17.0 \mathrm{~b}$ \\
Pc01-07 & $14.0 \mathrm{~b}$ & $12.5 \mathrm{~b}$ \\
Pc17-07 & $12.3 \mathrm{~b}$ & $10.3 \mathrm{~b}$ \\
Uninoculated & $0.0 \mathrm{a}$ & $0.0 \mathrm{a}$ \\
\hline
\end{tabular}

${ }^{\mathrm{z}}$ Mycelia: wounded twigs were inoculated with a mycelia plug $5 \mathrm{~mm}$ in diameter. Conidia: wounded twigs were inoculated with $15 \mu \mathrm{l}$ of a conidial suspension $\left(10^{6}\right.$ conidia $\left./ \mathrm{ml}\right)$. Means in each column followed by the same letter are not significantly different according to Tukey's test $(P=0.05)$.

our identifications. However, in spite of the important morphological differences obtained between Pestalotiopsis neglecta and T. angustata, a $100 \%$ homology was obtained between isolates of these two species. Jeewon et al. (12) has postulated a paraphylletic rather than monophylletic relation of the species of Truncatella that may partially explain our finding.

Our results demonstrated that $P$. clavispora, $P$. neglecta, and $T$. angustata were pathogenic to blueberry. It was possible to reproduce the canker and twig dieback symptoms in different blueberry cultivars, as was observed in commercial plantings. These pathogens were consistently isolated from inoculated plants, confirming Koch's postulates.

Previously, $P$. guepinii was identified on blueberry associated with leaf and shoot symptoms in southern Chile (7). This species is morphologically distinguishable from $P$. clavispora and P. neglecta, which were the Pestalotiopsis spp. found in this study. Similarly, the isolates of $P$. clavispora and $P$. neglecta were distant from $P$. guepinii on the basis of ITS regions of the DNA analysis performed. Nevertheless, these results do not discharge the presence of $P$. guepinii on blueberry in Chile.

Table 5. Susceptibility of blueberry (Vaccinium spp.) cultivars to Pestalotiopsis clavispora determined in 2-year-old plants 15 days postinoculation using mycelia

\begin{tabular}{lcccc}
\hline & \multicolumn{4}{c}{ Length $(\mathbf{m m})$ of cankers obtained with P. $_{\text {clavispora }} \mathbf{z}$} \\
\cline { 2 - 5 } Cultivars, analysis & Pc3-06 & Pc9.1-06 & Pc17-07 & Means \\
\hline Brightwell & 34.3 & 26.5 & 23.8 & $28.2 \mathrm{a}$ \\
O'Neal & 38.5 & 25.5 & 19.3 & $27.8 \mathrm{a}$ \\
Elliot & 30.8 & 22.0 & 14.3 & $22.3 \mathrm{ab}$ \\
Brigitta & 26.3 & 17.5 & 20.3 & $21.3 \mathrm{ab}$ \\
Dukes & 21.5 & 23.0 & 13.3 & $19.3 \mathrm{ab}$ \\
Misty & 20.8 & 16.8 & 14.0 & $17.2 \mathrm{~b}$ \\
Bluecrop & 18.8 & 16.3 & 13.5 & $16.2 \mathrm{~b}$ \\
Means & $26.1 \mathrm{~A}$ & $20.2 \mathrm{~B}$ & $15.8 \mathrm{C}$ & $\ldots$ \\
Variance analysis & & & & \\
Effects & $\mathrm{df}$ & $F$ & $P$ & \\
Cultivars (C) & 6 & 5.02 & 0.006 & \\
Isolates (I) & 2 & 14.81 & $<0.001$ & \\
C $\times$ I & 12 & 0.70 & 0.74 & \\
\hline
\end{tabular}

${ }^{\mathrm{z}}$ Means in each column followed by the same lowercase letter and in a row followed by the same uppercase letter are not significantly different according to Tukey's test $(P=0.05)$.

Pathogenic isolates of these species were obtained from $V$. corymbosum (cvs. Aurora, Bluecrop, Brigitta, Elliot, Legacy, and Liberty) and $V$. corymbosum $\times V$. darrowi (cvs. Cooper, Duke, Marimba, and O'Neal) farms and nurseries, located in areas with very different climate conditions, in an extensive geographical area of approximately $1,000 \mathrm{~km}$, from northern to southern Chile (27). However, P. clavispora was the species more frequently isolated, followed by T. angustata and P. neglecta. It is important to indicate that, previously, $P$. guepinii was identified as a canker-causing agent of blueberry in Argentina (8).

Regardless of the species, infection was only possible after wound inoculations, suggesting that wounds are needed for penetration in nature. Therefore, pruning wounds or other physical injuries may play an important role in disease development because it was frequently found under commercial conditions $(17,22,29)$.

The ability of $P$. clavispora, $P$. neglecta, and T. angustata to infect fruit of species other than blueberry suggests that they are not restricted to Vaccinium spp. Several studies have found non-host-specific isolates (13), and it has been postulated that wild vegetation may serve as a source of primary inoculum. This could be the case in Chile; however, further studies are needed to confirm this hypothesis.

The blueberry cvs. Bluecrop, Misty, and Briggita were the most resistant after twig inoculations using mycelia of $P$. clavispora, followed by cvs. Duke, Elliot, O'Neal, and Brightwell. However, Misty was susceptible to inoculations with conidia. Field trials appear to be necessary in order to reach a final conclusion.

It is interesting to remark that optimal temperature for mycelial growth was 25 and $20^{\circ} \mathrm{C}$ for isolates of $P$. clavispora obtained in the northern and southern blueberry production zones, respectively, which are characterized by relatively warm and cool climate conditions. These differences suggest the versatility and adaptability of these pathogens, as indicated for this and other Pestalotiopsis spp. (11).

Unexceptionally, $P$. clavispora was sensitive to fludioxonil and pyraclostrobin, with $\mathrm{EC}_{50}$ values between $0.06 \pm 0.02$ and $0.08 \pm 0.04 \mu \mathrm{g} / \mathrm{ml}$, respectively. These 
fungicides are considered to have a low toxicological profile. Thus, they could eventually be used to control these pathogens. Nevertheless, field condition studies are necessary before we recommend a spray regime (21).

In conclusion, the results of our study indicate that $P$. clavispora, $P$. neglecta, and $T$. angustata are primary pathogens that can cause canker lesions and dieback symptoms on blueberry. However, these results do not exclude the possibility that other species of these genera or other plant-pathogenic fungi (e.g., Botryosphaeria, Pestalotia, and Phomopsis spp.) may eventually be involved in this syndrome of blueberry.

\section{ACKNOWLEDGMENTS}

We thank Hortifrut-Viveros, Chile, Agrícola Trucao S.A., and Vital Berry Marketing S.A., Chile, for their contributions to completing these investigations; and P. Bañados and J. P. Zoffoli, Pontificia Universidad Católica de Chile, for their support in obtaining plants for the study as well as access to the production farms for plant samples.

\section{LITERATURE CITED}

1. Altschul, S. F., Gish, W., Millar, W., Myers, E. W., and Lipman, D. J. 1990. Basic local alignment search tool. J. Mol. Biol. 215:403-410.

2. Bañados, M. P. 2006. Blueberry production in South America. Acta Hortic. 715:165:172.

3. Barrau de los Santos, C., and Romero, F. 2006. Susceptibility of southern highbush and rabbiteye blueberry cultivars to postharvest disease in Huelva Spain. Acta Hortic. 715:525526.

4. CABI. 2007. Index fungorum. CABI Bioscience Databases Commonwealth Mycological Institute, England. (Accessed: December, 2007). www.indexfungorum.org/Index.htm.

5. Caruso F. L., and Ramsdell, D. C. 1995. Compendium of Blueberry and Cranberry Diseases. The American Phytopathology Society, St. Paul, MN.

6. Cline, B. 2004. Fungal pathogens associated with blueberry propagation beds in North Carolina. Small Fruits Rev. 3:213-221.

7. Cuevas, G., and Acuña, R. 2003. Detección de enfermedades del follaje en arándano (Vaccinium corymbosum L.) en la VIII Región Chile, XIII Congreso Sociedad Chilena de Fitopatología, V Región, Chile.

8. Fernández, R., Wright, E., Rosato, M., Pérez, B. A., Rivera, M., Divo de Sesar, M., Asciutto, K., and Aguilar, H. L. 2005. Sintomatología e incidencia de enfermedades ocasionadas Alternaria tenuísima y Pestalotiopsis guepinii, sobre órganos vegetativos de plantas de arándano (Vaccinium corymbosum). nota de enfermedad Actas XIII Congreso Latino- americano de Fitopatología. III Taller Argentino de Fitopatología. Villa Carlos Paz, Córdoba.

9. Guba, E. F. 1932. Monograph of Genus Pestalotia. Mycologia 24:355-397.

10. Hopkins, K. E., and McQuilken, M. P. 2000. Characteristics of Pestalotiopsis associated with hardy ornamental plants in the UK. Eur. J. Plant Pathol. 106:77-85.

11. Hu, H. L., Jeewon, R., Zhou, D. Q., Zhou, T. X., and Hyde K. D. 2007. Phylogenetic diversity of endophytic Pestalotiopsis species in Pinus armandii and Ribes spp. evidence from rDNA and $\beta$-tubulin gene phylogenies. Fungal Divers. 24:1-22.

12. Jeewon, R., Liew, E. C. Y., and Hyde, K. D. 2002. Phylogenetic relationships of Pestalotiopsis and allied genera inferred from ribosomal DNA sequences and morphological characters. Mol. Phylogenet. Evol. 25:378392.

13. Jeewon, R., Liew, E. C. Y., and Hyde, K. D. 2004. Phylogenetic evaluation of species nomenclature of Pestalotiopsis in relation to host association. Fungal Divers. 17:39-55.

14. Jeewon, R., Liew, E. C. Y., Simpson, J. A, Hodgkiss, I. J., and Hyde, K. D. 2003. Phylogenetic significance of morphological characters in the taxonomy of Pestalotiopsis species. Mol. Phylogenet. Evol. 27:372-383.

15. Jeon Y.H., Kim , S. G., and Kim Y. H. 2007. First report on leaf blight of Lindera obtusiloba caused by Pestalotiopsis microspora in Korea. Plant Pathol. 56:349-349.

16. Karakaya, A. 2001. First report of infection of kiwifruit by Pestalotiopsis sp. in Turkey. Plant Dis. 85:1028-1028.

17. Keith, L. M., Velásquez, M. E., and Zee F. T. 2006. Identification and characterization of Pestalotiopsis spp. causing scab disease of guava, Psidium guajava, in Hawaii. Plant Dis. 90:16-23.

18. Kinji, U., Nobuo, A., Nobuhira, K., and Junko O.1996. First report of Pestalotia disease, anthracnose and angular leaf spot of kiwifruit and their pathogens in Japan. Ann. Phytopathol. Soc. Jpn. 62:61-68.

19. Kobayashi, T., Ishihara, M., and Ono, Y. 2001. A new species of Pestalosphaeria, the teleomorph of Pestalotiopsis neglecta. Mycosciencie 42:211-216.

20. Liu, A. R., Xu, T., and Guo, L. D. 2007. Molecular and morphological description of Pestalotiopsis hainanensis sp. nov., a new endophyte from a tropical region of China. Fungal Divers. 24:23-36.

21. McGrath, M. T. 2004. What are Fungicides. The Plant Health Instructor. DOI: 10.1094/ PHI-I-2004-0825-01.

22. McQuilken, M. P., and Hopkins, K. 2004. Biology and integrated control of Pestalotiopsis on container-grown ericaceous crops. Pest Manage. Sci. 60:135-142.

23. Muñoz, C. 1993. Overview of the blueberry industry in South America. Acta Hortic.
346:2:32.

24. Nag Raj, T. R. 1993. Coelomycetous Anamorphs with Appendage-Bearing Conidia. Department of Biology, University of Waterloo, Mycologue Publications, Waterloo, Ontario, Canada.

25. NCBI. 2007. GenBank. National Center for Biotechnology Information. www.ncbi.nlm nih.gov/ (Accessed December, 2007).

26. Newcombe, G. 2000. First Report of Pestalotiopsis populi-nigrae on Poplar in North America. Plant Dis. 84:595.

27. Novoa R., and Villaseca, S. 1989. Mapa agro climático de Chile. Instituto de Investigaciones Agropecuarias, Santiago, Chile.

28. ODEPA-CIREN, 2007. Estadísticas de la agricultura Chilena. Oficina de Estudios y Políticas Agrarias, Ministerio de Agricultura, Gobierno de Chile. www.odepa.cl (Accessed: 27 October, 2007).

29. Rivera, M. C., and Wright, E. R. 2000. First report of azalea petal blight caused by Pestalotiopsis guepini in Argentina. Plant Dis. 84:100100.

30. Saitou, N., and Nei, M. 1987. The neighbor joining method: a new method for reconstructing phylogenetic trees. Mol. Biol. Evol. 4:406425 .

31. Schilder, A. M. C., Hancock, J. F., and Hanson, E. J. 2006 An integrated approach to disease control in blueberries in Michigan. Acta Hortic. 715:481:488.

32. Sutton, B. C. 1980. The Coelomycetes: Fungi Imperfecti with Pycnidia, Acervular and Stromata. Commonwealth Mycological Institute, Kew, Surrey, England.

33. Tagne, A., and Mathur, S. B. 2001. First report of chlorotic spot of maize caused by Pestalotiopsis neglecta. Plant Pathol. 50:791.

34. Thompson, J. D., Gibson, T. J., Plewniak, F., Jeanmougin, F., and Higgins, D. G. 1997. The ClustalX windows interface: flexible strategies for multiple sequence alignment aided by quality analysis tools. Nucleic Acids Res. 24:48764882.

35. Tuset, J. J., Hinarejos C., and Mira, J. L. 1999. First report of leaf blight on sweet persimmon tree by Pestalotiopsis theae in Spain. Plant Dis. 83:1070.

36. White, T. J., Bruns, T., Lee, S., and Taylor J. 1990. Amplification and direct sequencing of fungal ribosomal DNA genes for phylogenetics. Pages 315-321 in: PCR Protocols: A Guide to Methods and Applications. M. A. Innis, J. Gelfand, J. Sninky, and T., White, eds. Academic Press, San Diego, CA.

37. Wise J. C., Gut, L. J., Isaac ,R., Schilder, A. M. C., Sundin, G., Zandstra, B., and Hanson, E. 2004. Pages 128-136 in: Michigan Fruit Management Guide. Michigan State University, East Lansing.

38. Yasuda F., Kobayashi, T., Watanabe, H., and Izawa H. 2003. Addition of Pestalotiopsis spp. to leaf spot pathogens of Japanese persimmon. J. Genet. Plant Pathol. 69:29-32. 